\title{
Obituary Joanne Elda Holmes 27 July 1954 - 15 May 2012
}

Joanne Holmes was a respected and valued colleague, a champion for her people, a dearly loved wife, mother and grandmother, and a woman who met challenges with style. Joanne was born in Wynyard, Tasmania, a Palawa woman whose father died in the Hobart bushfires and whose mother subsequently moved to Melbourne. Joanne met and married Kevin Holmes in 1974 and, in the 1980s after having her first son, Matthew, decided to train as a teacher. After undertaking a number of teaching roles, Joanne had a second son, Jeremy, but 1992 brought ill health following a dental procedure and Joanne became the first Aboriginal woman to receive a liver transplant. Poor health dogged her footsteps on and off from this time on, but Joanne was unstoppable. She enrolled and completed a Bachelor of Social Work degree graduating with Honours in Social Work from the Institute of Koori Education at Geelong (Deakin University), and until her death maintained her determination to advocate passionately for services to children, young people and their families throughout the northern regions of Victoria and beyond.

Active participation, passion and enjoyment of life were hallmarks of Joanne's personality. Always facing her mortality, she was intent on achieving outcomes for others that made a real difference to their lives. This meant bringing to bear her creativity and modelling the lifelong learning she so valued. She was always a woman of principle and railed against any injustice. Joanne's interest was in helping the community and in achieving social justice. She recognised that vulnerable children had different needs, and was very clear that the needs of the Koori community were different to those of the dominant white population. She wanted Koori people to find their voice and went about developing programmes that would ensure her people were heard, and was especially passionate about people and organisations being accountable for their actions and particularly their work in relation to children.

Joanne was unique in her determination and capacity to continue working following her liver transplant and,

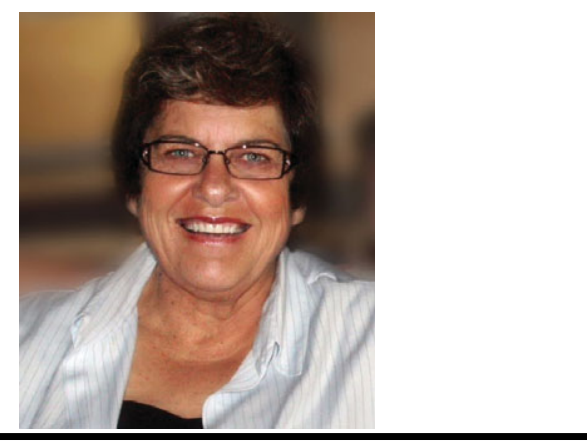

through the ensuing 20 years, she worked with the Department of Human Services, with the Centre Against Sexual Assault, and with the Kalianna Special School, amongst other agencies. Her networking was a key feature of her professionalism. She knew and worked with many organisations, never slowed by not having met someone before and was always ready to step forward, introduce herself and see what could be mutually gained through collegial cooperation. Along the way Joanne promoted and ran a number of initiatives, some of which endure through her focus on empowerment of both individuals and groups. Joanne was, for instance, a determined voice in the Aboriginal Family Decision Making Model which she led in northern Victoria. She was engaged in the Finding Yourself Programme and in developing the Bidja's Place Project, which included the famous Bidja Clan Puppets. Joanne's involvement in the Indigenous Family Violence Strategy resulted in her bringing an Elders group together, culminating in the purchase of a well-known Rochester homestead for the Aboriginal Healing Centre on behalf of all the regional Aboriginal communities: the Echuca Aboriginal community and Njernda, the Kyabram community, the Kerang community and the Bendigo community and Bendigo and District Aboriginal Cooperative (BDAC). It had been Joanne's vision that the healing centre would provide a standard for all others to match. 


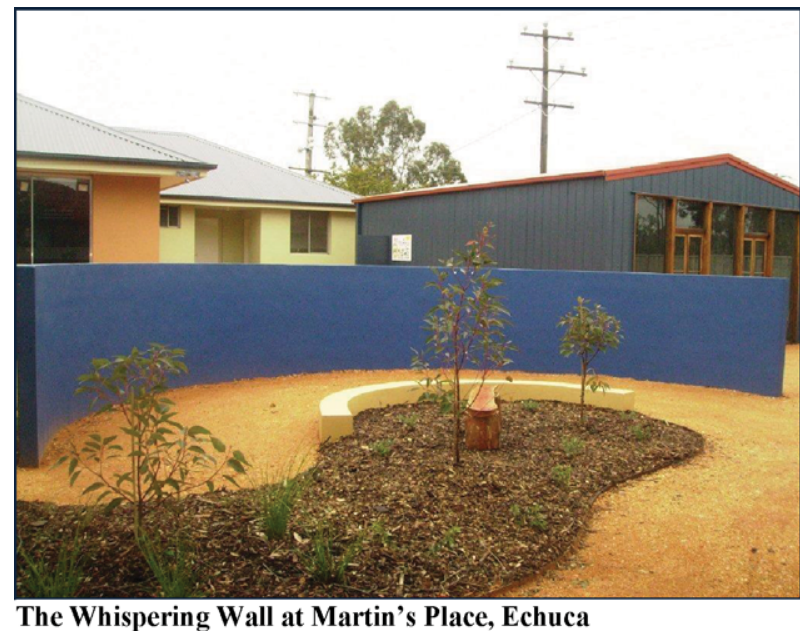

The Whispering Wall at Martin's Place, Echuca

And somewhere in between these efforts, Joanne and the Elders group developed purposeful engagement with inmates at Loddon Prison, producing a CD entitled 'Journey' and a calendar related to family violence. Their activities were extended to working in schools in the region to address issues of violence and sexual assault, with the additional result that the Elders group have become increasingly empowered; one of the group members is currently involved in a project to create awareness of Donor Organs that will target Aboriginal communities across Victoria. Joanne and the Elders group presented at many government and nongovernment organisation forums on their work, and because of the strength of their relationships and collaborations they have been listened to at the highest levels of government. Unfortunately, an invitation to address an international conference in Hawaii was not possible due to lack of funds.

None of this was easy for Joanne due to her need for regular contact with the Austin Hospital, but each time her health improved she seemed to find a new project to tackle. Spurred on by the question 'How do you give a dream to a child who has never dreamt?, Joanne's work in recent years rested on her dream of having a place for child counselling that would be in a physical space and environment that offered fun, play, safety and cultural appropriateness. Martin's Place in Echuca South was her final passion. She planned each room and its furnishings, and the garden with its whispering wall.

Sadly, Joanne was not to see Martin's Place come alive with children, young people and their families as a counselling venue, but her work will be carried on by her family, colleagues and friends. Early in 2012, her health became a serious concern and she was again in and out of the Austin, moving on into her Dreaming on 15 May 2012 - a great loss to her family, the Koori communities with whom she worked, and to us all. She is survived by her husband, Kevin, sons Matthew and Jeremy, and grandchildren. And the social work heritage they all carry is a powerful one.

My life has been a wonderful journey. I was put on this earth to do great things and I did. Don't underestimate yourselves, you'll come up against barriers and when you know what the barrier is, just figure out a way around or over.

Joanne Holmes 14 May 2012 